\title{
Reduction of Phosphorus Pollution from Broilers Waste through Supplementation of Wheat Based Broilers Feed with Phytase
}

\author{
Ahmed Abdel-Megeed ${ }^{1,2}$ and Arifa Tahir ${ }^{3}$ \\ ${ }^{1}$ Plant Protection Department, Faculty of Agriculture (Saba Basha), Alexandria University, Egypt \\ ${ }^{2}$ Botany and Microbiology Department, College of Science, King Saud University, P.O. Box 2455, Riyadh 11451, Saudi Arabia \\ ${ }^{3}$ Environmental Science Department, Lahore College for Women University, P.O. Box 54000, Lahore, Pakistan \\ Correspondence should be addressed to Ahmed Abdel-Megeed; aamahmoud@ksu.edu.sa
}

Received 23 September 2014; Accepted 27 February 2015

Academic Editor: Núria Fontanals

Copyright (C) 2015 A. Abdel-Megeed and A. Tahir. This is an open access article distributed under the Creative Commons Attribution License, which permits unrestricted use, distribution, and reproduction in any medium, provided the original work is properly cited.

\begin{abstract}
The present study was conducted to reduce phosphorus pollution from broilers waste by supplementing phytase enzyme in broilers fee. Two hundred two-week-old broilers (Hubbard) were selected and randomly allocated to three dietary treatment groups, one control group (without phytase) and two trial groups (group A with $300 \mathrm{U} / \mathrm{kg}$ phytase and group B with $600 \mathrm{U} / \mathrm{kg}$ phytase). Each group was composed of 5 replicates with 10 chicks. Broilers fed the control diet (without phytase) gained weight slower $(P<0.05)$ than the other treatment groups. A significant increase in body weight gain of group A (28.00 \pm 2.97$)$ and group B (29.75 \pm 3.45$)$ was observed as compared to control group $(26.75 \pm 2.78)$. The feed intake of the birds fed the diets containing microbial phytase $600 \mathrm{U} / \mathrm{kg}$ was the highest. Phytase significantly $(P>0.05)$ reduces excreta $\mathrm{P}$ and Ca level. Phytase addition did not affect excreta $\mathrm{pH}$. The presence of phytase in feed mixtures significantly $(P>0.05)$ improves the body weight gain and feed intake of broiler chickens.
\end{abstract}

\section{Introduction}

Phytase is a hydrolytic enzyme that releases phytate phosphorus, which represents 60 to 80 percent of the total phosphorus in plant-based feeds. Due to the lack of phytase in their gastrointestinal tracts, monogastric animals such as swine, poultry, and preruminant calves cannot digest phytate phosphorus. This results in the excretion of high levels of phosphorus in the manure of these animals $[1,2]$.

The enzyme phytase finds application in the hydrolysis of phytic acid (myo-inositol hexaphosphoric acid) and thus its metal chelating capability is eliminated and nutritional value of defatted oil seed cakes (canola meal, cotton seed meal, soybean meal, wheat, and mung beans) is enhanced. Several studies reported that phytase reduced the ileal flows of endogenous minerals and amino acids in broiler chickens, while phytate increased the excretion of endogenous amino acid [3-5]. The enzyme phytase catalyses the dephosphorylation of phytic acid and its salts, phytates. Supplementation of monogastric animal feed with microbial-derived phytase increases the bioavailability of phytic acid bound phosphate. This facilitates a reduction in the addition of inorganic phosphate to the feed and reduces phosphorus excretion [6].

The objective of this study was to reduce phosphorus excretion from poultry waste, reduce the feed cost of inorganic phosphorus supplementation, and preserve the nonrenewable inorganic phosphorus for sustainable agriculture.

\section{Material and Method}

2.1. Effect of Phytase on Body Weight and Food Intake Broiler Chicks. All experiments were conducted according to guidelines approved by the Animal Ethics Committee of Lahore College for Women University, Lahore, for the care and use of animals in research.

Two experiments were conducted to determine the effect of added microbial phytase on weight gain and feed intake of Hubbard broiler chicks. The broilers were housed in $2-x$ 4.34-m pens at a local poultry farm in 1 room of a ventilated tunnel house equipped with cool cells and fans. At two weeks 
of age, 200 chicks were divided into four groups each of 50 hens. Each group was composed of 5 replicates with 10 chicks each. They were held overnight without feed and water on the day before allotment to treatment. The broilers were then weighed and allotted to treatments in a completely randomized design. The experiment was conducted for 48 days. Both trails consisted of three treatments as follows:

(1) Control group: diet contains no phytase enzyme;

(2) Group A: low phosphorous diet contains $300 \mathrm{PU} / \mathrm{kg}$ diet;

(3) Group B: low phosphorous diet contains $600 \mathrm{PU} / \mathrm{kg}$ diet.

Ingredients of the diet are shown in Table 1.

Experiment 1. Chicks were weighed on weekly basis till the end of the experiment which lasted for 48 days. Body weight was weekly recorded and weight gain was calculated.

Experiment 2. In EXP 2, feed intake to body weight gain ratio (FCR) was recorded daily.

2.2. Analysis of $\mathrm{pH}, \mathrm{Ca}$, and $\mathrm{P}$ of Excreta Samples. The excreta were collected in plastic sheets. The excreta samples were mixed and homogenized individually. The $\mathrm{pH}$ of $1.0 \mathrm{~g}$ of excreta in $10 \mathrm{~mL}$ of distilled water was measured using a digital $\mathrm{pH}$ meter. The level of ash, $\mathrm{Ca}$, and $\mathrm{P}$ in excreta was determined by standard method [7].

2.3. Statistical Analysis. The data on various parameters were tabulated and subjected to statistical analysis using computer software Costat, cs 6204W.exe.

\section{Results and Discussion}

A significant increase in body weight gain of group A (28.00 \pm $2.97)$ and group B $(29.75 \pm 3.45)$ was observed as compared to control group $(26.75 \pm 2.78)$. The effect of supplementation of phytase on daily feed intake is presented in Table 2.

It was observed that chicks fed diet supplemented with phytase had significantly superior body weight gains as compared with control group. This indicates the synergetic effect of phytase for improving the growth performance. The improved growth due to phytase supplementation indicates that phytic acid is a growth limiting factor for chicks [8]. Our results are in complete agreement with observation of other workers $[9,10]$. This may be due to the improved nutrients absorption especially crude protein which complicates with phytate and inhibit other proteolytic enzymes such as pepsin and trypsin [10-13]. The improvement in body weight gain of chicks fed phytase-supplemented diets could be attributed to the improvement in availability of protein, essential amino acids, metabolisable energy, and minerals for animal growth [8]. Phytase enzyme supplementation improved $(P<0.05)$ feed intake in broilers fed P-deficient diets. The feed intake of the birds fed the diets containing microbial phytase $600 \mathrm{U} / \mathrm{kg}$ was the highest, following the $300 \mathrm{U} / \mathrm{kg}$ enzyme group and control group, respectively (Table 2). These differences
TABLE 1: Ingredients and composition of experimental diets.

\begin{tabular}{|c|c|c|c|}
\hline Feeds & $\begin{array}{c}\text { Control } \\
(\mathrm{g} / 100 \mathrm{~g}) \\
\end{array}$ & $\begin{array}{l}\text { Group A } \\
(\mathrm{g} / 100 \mathrm{~g})\end{array}$ & $\begin{array}{l}\text { Group B } \\
(\mathrm{g} / 100 \mathrm{~g})\end{array}$ \\
\hline Wheat & 65.00 & 65.00 & 65.00 \\
\hline Soybean meal & 14.86 & 14.86 & 14.86 \\
\hline Sunflower meal & 7.62 & 7.62 & 7.62 \\
\hline Vegetable oil & 0.92 & 0.92 & 0.92 \\
\hline Salt & 0.50 & 0.50 & 0.50 \\
\hline DL-methionine & 0.12 & 0.12 & 0.12 \\
\hline L-lysine & 0.17 & 0.17 & 0.17 \\
\hline Vitamin premix & 0.25 & 0.25 & 0.25 \\
\hline Mineral premix & 0.25 & 0.25 & 0.25 \\
\hline Dicalcium phosphate & 1.33 & 1.33 & 1.33 \\
\hline Ground limestone & 8.98 & 8.98 & 8.98 \\
\hline Phytase enzyme (U/kg) & - & 300 & 600 \\
\hline \multicolumn{4}{|c|}{ Chemical analysis (DM basis) } \\
\hline Dry matter $(\%)$ & 89.27 & 89.30 & 89.32 \\
\hline Crude protein $(\%)$ & 15.00 & 15.03 & 15.02 \\
\hline Crude cellulose (\%) & 4.28 & 4.29 & 4.29 \\
\hline Ash (\%) & 13.65 & 13.63 & 13.62 \\
\hline Ether extract (\%) & 6.04 & 6.06 & 6.03 \\
\hline Calcium (\%) & 3.75 & 3.70 & 3.73 \\
\hline Phosphorus (\%) & 0.42 & 0.41 & 0.42 \\
\hline Methionine (\%) & 0.60 & 0.61 & 0.61 \\
\hline Lysine (\%) & 0.79 & 0.78 & 0.77 \\
\hline Linoleic acid (\%) & 1.83 & 1.82 & 1.84 \\
\hline
\end{tabular}

(Source: Hi-Tech Feed, Lahore, Pakistan).

among the groups were due to the use of microbial phytase enzyme amount in diets. Our findings are supported by other workers [12-14].

The improved feed intake with phytase may be due to release of phosphorus, which is potential for other nutrients to show a higher availability. In particular, positively charged (cationic) minerals such as calcium, zinc, copper, cobalt, iron, magnesium, nickel, and manganese are all known to form complexes with phytate and show higher digestibility values in the presence of phytase.This finding is consistent with other workers $[2,14]$.

3.1. Effect of Phytase on Phosphorus Content, $\mathrm{pH}$, and $\mathrm{Ca}$ in Broiler Chickens' Excreta. Effects of phytase supplementation on the excreta $\mathrm{pH}, \mathrm{Ca}$, and $\mathrm{P}$ are presented in Table 3. Dietary treatments have significant effect on excreta $\mathrm{pH}$. Significant reduction of $\mathrm{P}$ excretion was observed by phytase supplementation of diet. P reduction was $40 \%$ in group B and $28 \%$ in group A as compared to control. According to another researcher, the reduction of $\mathrm{P}$ excretion was $41 \%$ with the low $P$ diet and supplementary phytase [15].

Microbial phytase improved availability of phytate phosphorus in layer diets [16]. In the present study excreta $\mathrm{Ca}$ content was 50\% reduced as compared to control. Literature is lacking reports on the influence of phytase on availability of 
TABLE 2: Effect of dietary supplementation of microbial phytase on body weight gain and feed intake.

\begin{tabular}{lcccccc}
\hline Age (week) & Control & $\begin{array}{c}\text { Body weight gain (g) } \\
\text { Group (A) }\end{array}$ & Group (B) & Control & $\begin{array}{c}\text { Feed intake (g) } \\
\text { Group (A) }\end{array}$ & Group (B) \\
\hline 3 & 20 & 21 & 21 & 34 & 33 & 35 \\
4 & 25 & 26 & 28 & 47 & 63 & 65 \\
5 & 29 & 30 & 33 & 74 & 67 & 71 \\
6 & 33 & 35 & 37 & & & 80 \\
\hline
\end{tabular}

TABLE 3: Effects of diet inclusion with two phytase levels (300 and $600 \mathrm{~g} / 100 \mathrm{~g}$ ) on excreta parameters ( $\mathrm{pH}, \mathrm{Ca}$, and $\mathrm{P})$.

\begin{tabular}{lccc}
\hline Parameter & Excreta pH & Excreta Ca (\%ash) & Excreta P (\%ash) \\
\hline Control & 7.59 & 6.15 & 0.78 \\
Group A & 7.48 & 4.22 & 0.59 \\
Group B & 7.15 & 3.07 & 0.47 \\
\hline
\end{tabular}

$\mathrm{Ca}$ in broilers. We suppose that microbial phytase improved availability of Ca.

\section{Conclusion}

Our findings showed that phytase should be a mandatory feed additive. The use of a fungal phytase as a feed supplement proved effective in alleviating the negative effects of phytate in livestock diets and provided an improvement on feed intake and body weight.

\section{Conflict of Interests}

The authors declare that there is no conflict of interests regarding the publication of this paper.

\section{Acknowledgment}

The authors extend their appreciation to the Deanship of Scientific Research at King Saud University for funding this work through research group "RGP 010."

\section{References}

[1] M. Rezaei, S. Borbor, M. Zaghari, and A. Teimouri, "Effect of phytase supplementation on nutrients availability and performance of broiler chicks," International Journal of Poultry Science, vol. 6, no. 1, pp. 55-58, 2007.

[2] J. Remus, "Poultry and environment reap the benefits of newgeneration phytase," Feedtech: International Feed Production and Applied Nutrition, vol. 9, pp. 22-25, 2005.

[3] A. J. Cowieson and V. Ravindran, "Effect of phytic acid and microbial phytase on the flow and amino acid composition of endogenous protein at the terminal ileum of growing broiler chickens," British Journal of Nutrition, vol. 98, no. 4, pp. 745752, 2007.

[4] R. J. Wodzinski and A. H. J. Ullah, "Phytase," Advances in Applied Microbiology, vol. 42, pp. 263-302, 1996.
[5] G. Q. Lan, N. Abdullah, S. Jalaludin, and Y. W. Ho, "Efficacy of supplementation of a phytase-producing bacterial culture on the performance and nutrient use of broiler chickens fed cornsoybean meal diets," Poultry Science, vol. 81, no. 10, pp. 15221532, 2002.

[6] A. Boyce and G. Walsh, "Comparison of selected physicochemical characteristics of commercial phytases relevant to their application in phosphate pollution abatement," Journal of Environmental Science and Health, Part A: Toxic/Hazardous Substances and Environmental Engineering, vol. 41, no. 5, pp. 789-798, 2006.

[7] AOAC, Official Methods of Analysis 1, 1990.

[8] P. K. Singh, "Significance of phytic acid and supplemental phytase in chicken nutrition: a review," World's Poultry Science Journal, vol. 64, no. 4, pp. 553-580, 2008.

[9] A. K. Kies, K. H. F. van Hemert, and W. C. Sauer, "Effect of phytase on protein and amino acid digestibility and energy utilisation," World's Poultry Science Journal, vol. 57, no. 2, pp. 109-126, 2001.

[10] M. Ciftci, B. Dalkilic, and M. A. Azman, "Effects of microbial phytase supplementation on feed consumption and egg production of laying hens," International Journal of Poultry Science, vol. 4, no. 10, pp. 758-760, 2005.

[11] V. Ravindran, S. Gabahug, G. Ravindran, P. H. Selle, and W. L. Bryden, "Response of broiler chickens to microbial phytase supplementation as influenced by dietary phytic acid and nonphytate phosphorous levels. II. Effects on apparent metabolisable energy, nutrient digestibility and nutrient retention," British Poultry Science, vol. 41, no. 2, pp. 193-200, 2000.

[12] K. Y. El-Nagmy, M. O. Abd-Elsamee, and M. R. M. Ibrahim, "Effect of dietary plant protein and microbial phytase levels on performance of broiler chicks, Egypt," Poultry Science, vol. 24, pp. 101-121, 2004.

[13] X. Zhang, D. A. Roland, G. R. Mcdaniel, and S. K. Rao, "Effect of natuphos phytase supplementation to feed on performance and ileal digestibility of protein and amino acids of broilers," Poultry Science, vol. 78, no. 11, pp. 1567-1572, 1999.

[14] M. A. Jalal and S. E. Scheideler, "Effect of supplementation of two different sources of phytase on egg production parameters in laying hens and nutrient digestibility," Poultry Science, vol. 80, no. 10, pp. 1463-1471, 2001.

[15] J. S. Um and I. K. Paik, "Effects of microbial phytase supplementation on egg production, eggshell quality, and mineral retention of laying hens fed different levels of phosphorus," Poultry Science, vol. 78, no. 1, pp. 75-79, 1999.

[16] N. N. Toprak and A. Yilmaz, "Effects of phytase and DCP supplementation on performance, egg quality, some serum, tibia and excreta characteristics of barley based protein deficient quail diets," Macedonian Journal of Animal Science, vol. 2, no. 4, pp. 389-396, 2012. 

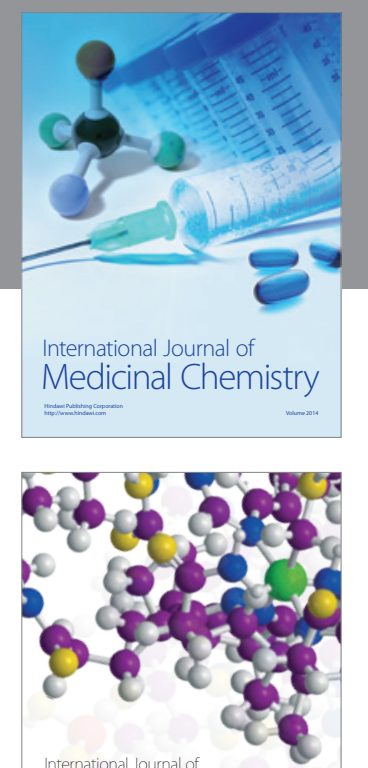

\section{Carbohydrate} Chemistry

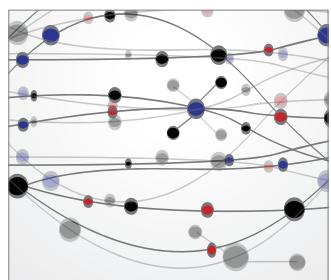

The Scientific World Journal
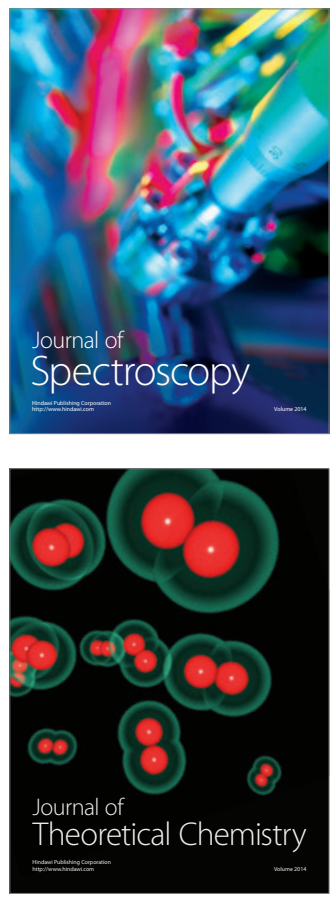
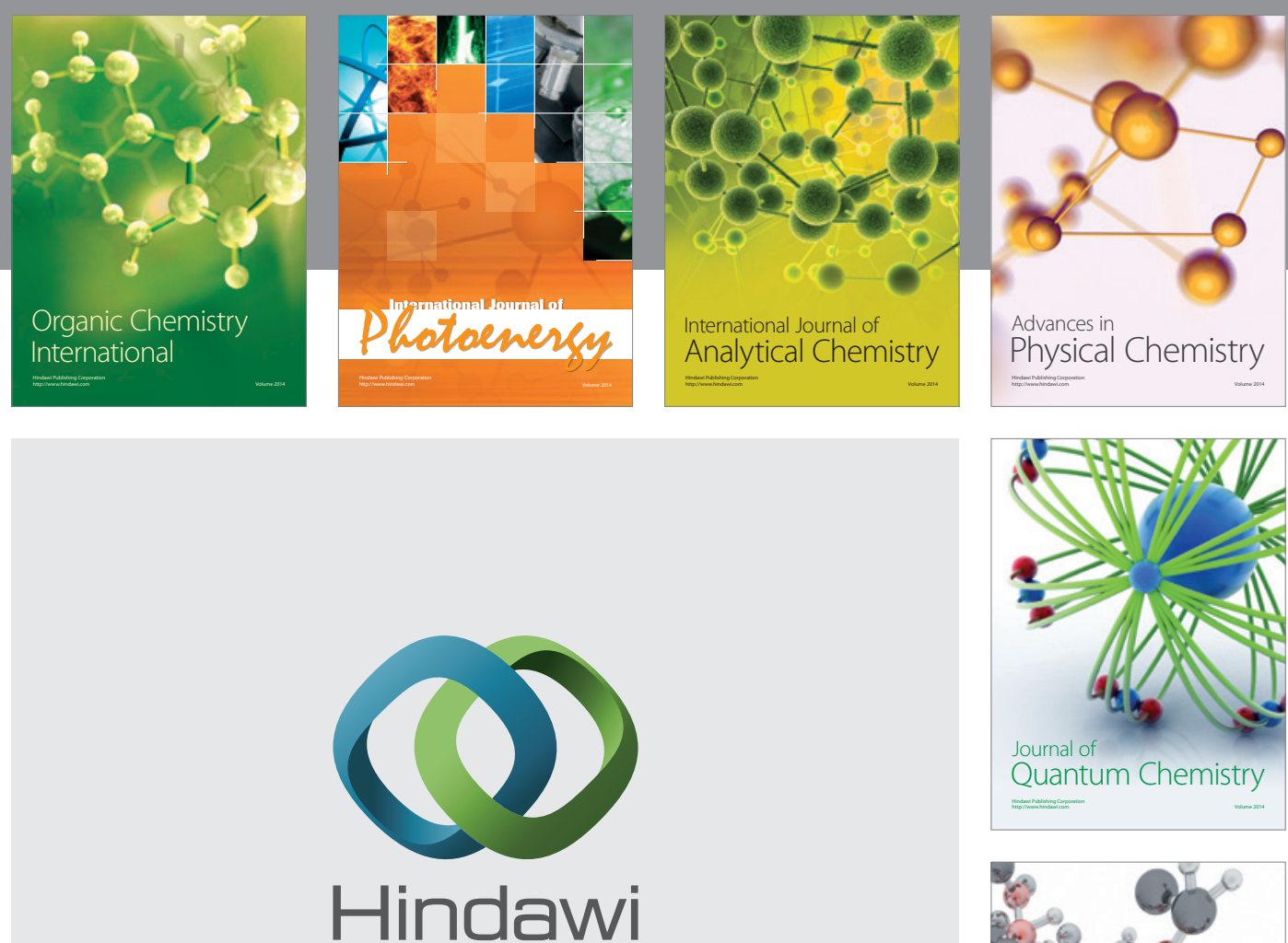

Submit your manuscripts at

http://www.hindawi.com

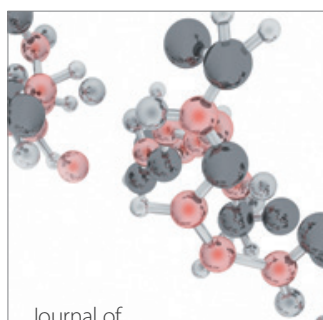

Analytical Methods

in Chemistry

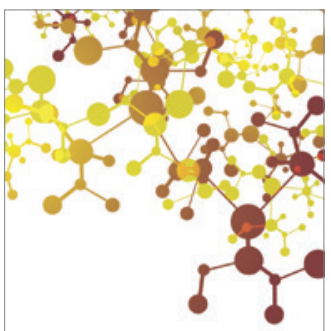

Journal of

Applied Chemistry

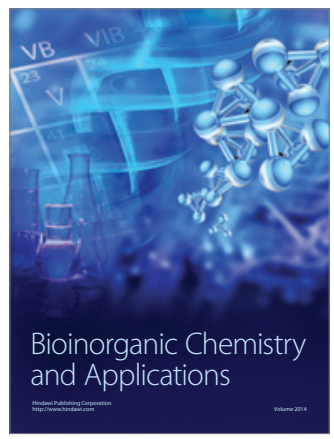

Inorganic Chemistry
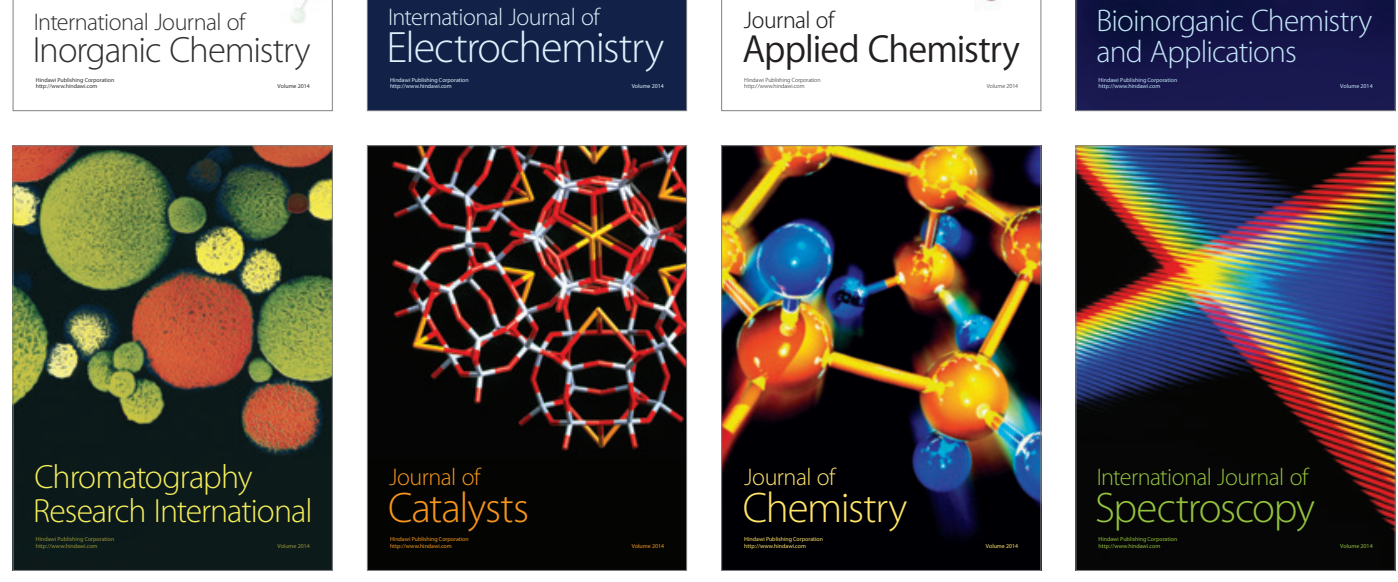